\title{
Offshore wind farms as productive sites or ecological traps for gadoid fishes? - Impact on growth, condition index and diet composition
}

\author{
Jan T. Reubens ${ }^{\mathrm{a}, *}$, Sofie Vandendriessche ${ }^{\mathrm{b}}$, Annemie N. Zenner ${ }^{\mathrm{c}}$, Steven Degraer ${ }^{\mathrm{d}, \mathrm{a}}$, \\ Magda Vincx ${ }^{\mathrm{a}}$ \\ ${ }^{a}$ Ghent University, Department of Biology, Marine Biology Research Group, Krijgslaan 281/S8, 9000 Gent, Belgium \\ ${ }^{\mathrm{b}}$ Institute for Agricultural and Fisheries Research, Aquatic Environment and Quality, Bio-Environmental Research Group, Ankerstraat 1, 8400 Ostend, \\ Belgium \\ ${ }^{c}$ Institute for Agricultural and Fisheries Research, Aquatic Environment and Quality, Fisheries Biology Group, Ankerstraat 1, 8400 Ostend, Belgium \\ ${ }^{\mathrm{d}}$ Royal Belgian Institute of Natural Sciences, Management Unit of the North Sea Mathematical Models (MUMM), Marine Ecosystem Management Section, \\ Gulledelle 100, 1200 Brussels, Belgium
}

\section{A R T I C L E I N F O}

\section{Article history:}

Received 8 April 2013

Received in revised form

29 May 2013

Accepted 30 May 2013

\section{Keywords:}

Ecological trap

Productivity

Fitness

Atlantic cod

Pouting

Wind power

Artificial habitats

\begin{abstract}
A B S T R A C T
With the construction of wind farms all across the North Sea, numerous artificial reefs are created. These windmill artificial reefs (WARs) harbour high abundances of fish species which can be attracted from elsewhere or can be the result of extra production induced by these wind farms. To resolve the attraction-production debate in suddenly altered ecosystems (cf. wind farms), the possible consequences of attraction should be assessed; thereby bearing in mind that ecological traps may arise. In this paper we investigated whether the wind farms in the Belgian part of the North Sea act as ecological traps for pouting and Atlantic cod. Length-at-age, condition and diet composition of fish present at the windmill artificial reefs was compared to local and regional sandy areas.

Fish data from the period 2009-2012 were evaluated. Mainly I- and II-group Atlantic cod were present around the WARs; while the 0 - and I-group dominated for pouting. For Atlantic cod, no differences in length were observed between sites, indicating that fitness was comparable at the WARs and in sandy areas. No significant differences in condition index were observed for pouting. At the WARs, they were slightly larger and stomach fullness was enhanced compared to the surrounding sandy areas. Also diet differed considerably among the sites. The outcome of the proxies indicate that fitness of pouting was slightly enhanced compared to the surrounding sandy areas. No evidence was obtained supporting the hypothesis that the WARs act as an ecological trap for Atlantic cod and pouting.
\end{abstract}

(c) 2013 Elsevier Ltd. All rights reserved.

\section{Introduction}

Offshore wind energy production is an important contributor to the renewable energy production in Europe. All across the North Sea offshore wind farms (OWFs) are planned, being constructed or already operational (Arapogianni et al., 2013; Brabant et al., 2012). With the construction of wind turbines, thousands of artificial reefs (so-called Windmill Artificial Reefs, WARs) will be present in an ecosystem which is naturally composed of softbottom sediments. As a result, the OWFs induce some changes

\footnotetext{
* Corresponding author. Tel.: +32 926485 17; fax: +32 92648598.

E-mail addresses: Jan.Reubens@UGent.be (J.T. Reubens), sofie.vandendriessche@ ilvo.vlaanderen.be (S. Vandendriessche), annemie.zenner@ilvo.vlaanderen.be (A.N. Zenner), Steven.Degraer@MUMM.ac.be (S. Degraer), Magda.Vincx@UGent.be (M. Vincx).
}

in the marine environment which may influence local biodiversity and ecosystem functioning (Andersson et al., 2009).

These artificial reefs often harbour high densities of several benthic and benthopelagic fish species (Leonhard et al., 2011; Reubens et al., 2013a; Winter et al., 2010). Two models have been proposed to explain the increased fish abundances (Brickhill et al., 2005). The attraction hypothesis suggests that fish move from the surrounding environment towards the reef. They aggregate at the reef, but there is no net increase in local population. The fish are only concentrated into a smaller area. The production hypothesis on the other hand, assumes that the carrying capacity of the environment increases as a result of the new habitat. More fish are able to settle, survive, grow and contribute to the local population, resulting in net production (both in biomass and in abundance) (Brickhill et al., 2005; Lindberg, 1997; Pickering and Whitmarsh, 1997).

Whether density and biomass increases are the result of attraction or if production is also involved still needs to be resolved 
in many cases and the outcome depends on a multitude of factors. Different fishes react differently to these new substrates as their dependence upon (artificial) hard substrates varies across species, environment, location and age-specific requirements (Brickhill et al., 2005). Also the reef design, location and abundance of reef units influence fish behaviour (Pickering and Whitmarsh, 1997). In many cases attraction and production are not mutually exclusive and may interact with one another. An initial attraction of a fish species may, in time, turn into production.

To resolve the attraction-production debate, one should focus on the possible consequences of attraction first. Negative ecological consequences for fish may arise from attraction. In suddenly altered ecosystems (as is the case for the construction of offshore wind farms) ecological traps may arise. When an organism is attracted to, and preferably settles in a habitat with suboptimal conditions relative to other available habitats, it is caught in a so-called ecological trap (Robertson and Hutto, 2006). Habitat choices are a consequence of natural selection and are based upon a number of ecological cues which indicate the quality status of a habitat (Schlaepfer et al., 2002). An ecological trap may occur when changes in the environment act to uncouple the cues used to assess habitat quality from the true quality of the environment (Robertson and Hutto, 2006). In the marine environment, fish aggregation devices for instance are known to have the potential as ecological traps (Hallier and Gaertner, 2008). Although, they also may have the potential to increase the condition and reproductive outcome of fishes (Dempster et al., 2011).

In the Belgian Part of the North Sea (BPNS) the seabed is dominated by soft-bottom sediments, while natural hard substrates are rare (Mallefet et al., 2008). In recent years, the construction of OWFs created numerous WARs.

Atlantic cod (Gadus morhua) and pouting (Trisopterus luscus) are two gadoid species that often occur at these WARs in the BPNS (Reubens et al., 2013a). Atlantic cod is a benthopelagic fish species that occurs in the North Atlantic Ocean. It is widely distributed throughout the North Sea in a variety of habitats and is a highly valued commercial species, severely suffering from overexploitation (ICES, 2012). Pouting is also a benthopelagic fish, but smaller than cod and occurring from the Skagerrak to the African coast. It lives in soft sand or rocky areas and often occurs in large schools (Merayo and Villegas, 1994). It is a commercial species in southern European countries (Merayo, 1996b).

Both species are known to be attracted to the WARs in the BPNS and high catch rates are observed during summer and autumn (Reubens et al., 2013a, 2011). In addition, acoustic telemetry revealed that Atlantic cod is highly resident at WARs (Reubens et al., submitted for publication). However, whether the WARs are poorer or richer in habitat quality than the surrounding softbottom sediments remains unknown. Each habitat has its own community structure and carrying capacity, influenced by environmental parameters (e.g. currents, heterogeneity, temperature, sediment type). As a result, habitat selectivity influences the fitness of the associated fishes. Fitness is represented by growth, condition index and diet; and all three may differ or be affected by the environmental differences among habitats.

In this paper we investigated growth, condition and diet (i.e. proxies for fitness) of pouting and Atlantic cod at different sites in the North Sea. Proxy values at the WARs were compared to values from sandy areas to resolve whether the WARs act as ecological traps for these species. The values were compared locally (i.e. close to the WARs), and regionally (i.e. BPNS and ICES area IVc).

\section{Materials and methods}

\subsection{Study sites and data collection}

Pouting and Atlantic cod were sampled from January 2009 until December 2012 at WARs and at sandy areas (i.e. Goote Bank, BPNS and ICES area IVc). The WARs under investigation are located at an OWF in the BPNS (Fig. 1), more precisely at the Thorntonbank, a natural sandbank $27 \mathrm{~km}$ offshore (coordinates WGS 84: 51 ${ }^{\circ} 33^{\prime} \mathrm{N}-$ $2^{\circ} 56^{\prime} \mathrm{E}$ ) (C-Power concession). Water depth varies between 18 and
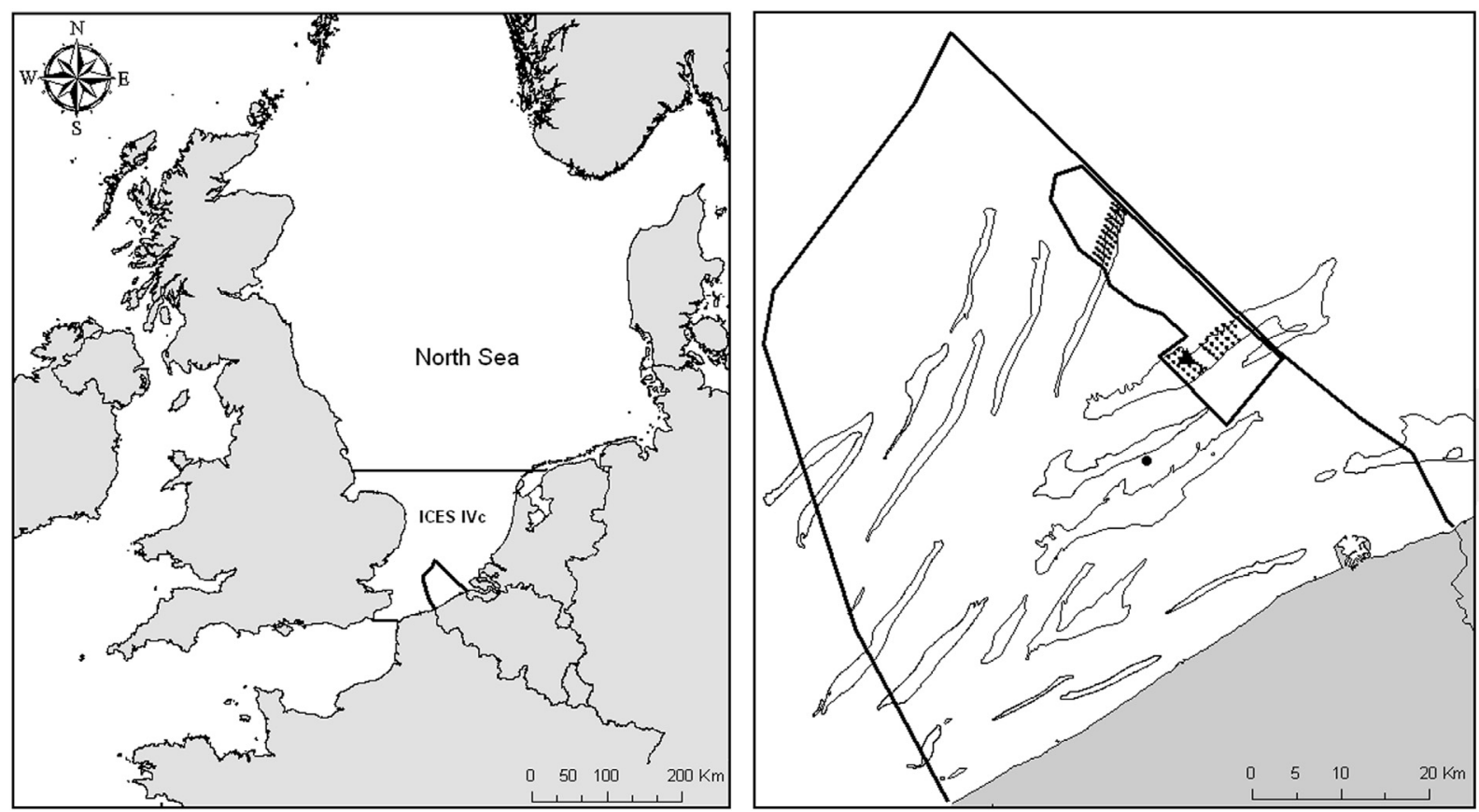

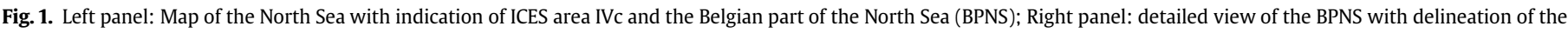
windmill zone and indication of the installed wind turbines. Sampling locations at the Windmill artificial reefs (black triangle) and the sandy area (black circle) are indicated. 
$24 \mathrm{~m}$ in the wind farm. It consists of 54 wind turbines (spread over $18 \mathrm{~km}^{2}$ ), with two types of foundations: concrete gravity based (6 turbines) and steel jacket foundations with four legs (48 turbines). Both function as WARs.

All fish from the WARs were caught at the gravity based foundations. These foundations have a diameter of $14 \mathrm{~m}$ at the seabed, at a depth of about $22.5 \mathrm{~m}$ at mean low water spring (MLWS). They are surrounded by a scour protection layer of pebbles and rocks with a maximum width of $18 \mathrm{~m}$. The total surface area of the hard substrates (turbine foundation and scour protection together) is approximately $1500 \mathrm{~m}^{2}$. The surrounding soft sediment is composed of medium sand (mean median grain size $374 \mu \mathrm{m}$, SE $27 \mu \mathrm{m}$ ) (Reubens et al., 2009). The sandy area sampled for local comparison (called Goote Bank hereafter) is located at the Goote Bank (coordinates WGS 84: $51^{\circ} 27^{\prime} \mathrm{N}-2^{\circ} 52^{\prime} \mathrm{E}$ ) at approximately $25 \mathrm{~m}$ depth at MLWS. The area is composed of medium sand (mean median grain size $371 \mu \mathrm{m}$, SE $83 \mu \mathrm{m}$ ) (Reubens et al., 2009). For regional comparisons, data concerning Atlantic cod and pouting were extracted from the databases from the institute for Agricultural and Fisheries Research (ILVO). Data from the BPNS (Aquatic Environment Database) and the ICES area IVc (Fisheries Biology Database) were used. Both the BPNS and the Southern Bight (i.e. ICES area IVc) are characterised by a complex system of sand banks, which are orientated parallel to the coasts. The seabed consists mainly of medium to fine-grained sands, but mud deposits are present as well. The BPNS is a small part of the North Sea (only $3600 \mathrm{~km}^{2}$ ), it is a shallow sea with an average depth of $20 \mathrm{~m}$ and maximum depth of $46 \mathrm{~m}$. The Southern Bight of the North Sea is bordered by France, Belgium, The Netherlands and the UK (Fig. 1). It is delimited to the north around $53^{\circ} \mathrm{N}$ and to the south by the Dover Strait. The Southern bight has a maximum depth of $54 \mathrm{~m}$ (Degraer et al., 2006; Jones et al., 2004; Kerckhof and Houziaux, 2003; Merckx, 2011).

At the WARs and the Goote Bank fishes were collected by standardized line fishing (hooks: Arca size 4; bait: Arenicola marina). Sampling was restricted to daytime hours. Fishing time was $45 \mathrm{~min}$ on average and the number of fishermen ranged from 2 to 8 . At the WARs, angling was performed 1-10 $\mathrm{m}$ away from a turbine (i.e. within the erosion protection layer radius) just above the bottom of the seabed, assuring catching WAR associated individuals. The fish were measured (total length) and weighed (wet weight), and their stomachs were removed and preserved in an $8 \%$ formaldehyde-seawater solution.

At the BPNS, fish were caught with an 8-m beam trawl with a fine-meshed shrimp net (stretched mesh width $22 \mathrm{~mm}$ in the cod end) and a bolder-chain. The net was dragged for $30 \mathrm{~min}$ on average at an average speed of four knots over the bottom. For ICES area IVc data from both research and commercial vessels were used. Research vessels (bottom trawl surveys) used a 4-m beam trawl with a stretched mesh width of $40 \mathrm{~mm}$ in the cod end. The net was dragged for 30 min on average at an average speed of four knots over the bottom. Commercial vessels used nets with a stretched mesh width between 80 and $220 \mathrm{~mm}$ and tows varied between $40 \mathrm{~min}$ and six hours at an average speed of four to seven knots. All fish were measured for total length.

Fulton's condition index was used as an indicator of the general condition of the fish. It was calculated as $F=\left(\mathrm{W} / \mathrm{TL}^{3}\right)^{*} 100$, where $W=$ total weight $(\mathrm{g})$ and $\mathrm{TL}=$ total length $(\mathrm{cm})$. The use of somatic weight (total weight minus gonad and stomach content weights) instead of total weight would have provided a more accurate reflection of condition, since feeding intensity and gonad maturation may vary significantly (both temporally and regionally) (Lambert and Dutil, 1997). Unfortunately data on somatic weight was mostly not available.

To quantify the feeding rate and investigate the prey composition in the diet, stomach content analyses were performed for pouting. All food components in the stomachs were identified to the lowest possible taxonomic level. Wet weight, dry weight $\left(60^{\circ} \mathrm{C}\right.$ for $48 \mathrm{~h}$ ) and ash-free dry weight $\left(500{ }^{\circ} \mathrm{C}\right.$ for $2 \mathrm{~h}$ ) were measured for all separate food contents in each stomach. Prey were later categorized in 10 groups: Anthozoa, Mysida, Amphipoda, Natantia, Reptantia, Mollusca, Echinodermata, Pisces, detritus and rest.

To investigate the patterns in feeding rates a stomach content fullness index $\left(I_{\mathrm{F}}\right)$ was calculated for each stomach of pouting as $I_{\mathrm{F}}=10000 \mathrm{cL}^{-3}$, where $c$ is the stomach content mass (wet weight, $\mathrm{g}$ ) and $L$ is the fish length (total length, $\mathrm{cm}$ ). Dietary composition was assessed by the frequency of occurrence (\% FO) and gravimetric abundance index (\% G). For the gravimetric analysis ash-free dry weight was used.

$\% \mathrm{FO}_{i}=\left(N_{i} / N\right) * 100$

$\% G_{i}=\left(\sum S_{i} / \sum S_{\mathrm{a}}\right) * 100$

$\mathrm{N}_{i}$ is the number of predators with prey type $i$ in their stomach, $N$ the total number of non-empty stomachs, $S_{i}$ is the stomach content composed by prey $i$ and $S_{\text {a }}$ the total stomach content of all stomachs together (Amundsen et al., 1996). Only non-empty stomachs were used in the analysis as regurgitation could have occurred while fish were being hauled.

As shown by Table 1, not all analyses could be performed for each region. For the data from the BPNS and ICES area IVc, only information on length of the fish was available; as a consequence nor condition, neither fullness index could be calculated for these fishes. For Atlantic cod, data for the local comparison (Goote Bank) were too sparse; due to the low catch rates and a scattered distribution throughout the year.

Only for the local comparison for pouting all three analyses (i.e. length-at-age, condition and diet composition) could be performed. For Atlantic cod and for the other regions only length-at-age information was available (Table 1). However, it was decided to use this data as well as each analysis provided useful information and contributed to resolve the main question of the study.

\subsection{Data analysis}

Length-frequency distributions were built to investigate the age composition in the population. It gives clear information concerning the age groups present and their length distributions. The younger age groups usually do not have much overlap in length distribution (Daan, 1974), which makes it easier to distinguish the different age groups.

No otolith information was available for data from the WARs, Goote Bank and BPNS. However, based on the length-frequency distributions the different cohorts of Atlantic cod and pouting present could be clearly separated. Age-length keys helped to correctly assign the cohorts to their age group. The key for Atlantic cod was compiled from data from the ICES area IVc for the period 2009-2012 (Table 2). For pouting, age-length information (Table 3)

\section{Table 1}

Overview of data available (X) per region. Data are from the period 2009-2012. For pouting no data was available from ICES area IVc; for Atlantic cod there was not sufficient data from the sandy area available for proper analysis.

\begin{tabular}{|c|c|c|c|c|c|c|c|c|}
\hline & \multicolumn{4}{|c|}{ Pouting } & \multicolumn{4}{|c|}{ Atlantic cod } \\
\hline & WAR & $\begin{array}{l}\text { Sandy } \\
\text { area }\end{array}$ & BPNS & IVc & WAR & $\begin{array}{l}\text { Sandy } \\
\text { area }\end{array}$ & BPNS & IVc \\
\hline Length & $\mathrm{X}$ & $\mathrm{X}$ & $\mathrm{X}$ & & $\mathrm{X}$ & & $\mathrm{X}$ & $X$ \\
\hline Condition & $\mathrm{X}$ & $\mathrm{X}$ & & & $\mathrm{X}$ & & & \\
\hline Diet & $\mathrm{X}$ & $\mathrm{X}$ & & & $\mathrm{X}$ & & & \\
\hline
\end{tabular}


Table 2

Age-length-key per quarter for Atlantic cod, based on data from the ICES area IVc in the period 2009-2012. Age was determined by otolith analysis. Values are expressed as total length $(\mathrm{cm})$. Q1 = Jan-Mar, Q2 = Apr-Jun, Q3 = Jul-Sep, $\mathrm{Q} 4=\mathrm{Oct}-\mathrm{Dec}$. The numbers between brackets indicate the number of fish available for age determination.

\begin{tabular}{lllll}
\hline & Q1 & Q2 & Q3 & Q4 \\
\hline 0 year & & & $16.8(6)$ & $19.9(71)$ \\
1 year & $26.5(39)$ & $29.7(173)$ & $35.2(127)$ & $43.3(715)$ \\
2 year & $49.3(184)$ & $51.0(925)$ & $53.2(262)$ & $54.6(594)$ \\
3 year & $64.1(180)$ & $68.3(283)$ & $65.0(13)$ & $61.2(687)$ \\
\hline
\end{tabular}

was based on Merayo and Villegas (1994) and the regression from standard length to total length $(\mathrm{TL}=2.35+1.102 \mathrm{SL}$ ) was based on Hamerlynck and Hostens (1993).

Separate length-frequency distributions were made for Atlantic cod and pouting from the WARs, Goote Bank and BPNS. For Atlantic cod from ICES area IVc otolith information was available for age determination.

The comparison of length and condition index between sites was separated per age group.

To investigate differences in fish size and Fulton's condition index between sites and months/seasons PERMANOVA was used. PERMANOVA makes no explicit assumptions regarding the distribution of original variables. Univariate and multivariate ANOVAs were performed with $p$-values obtained by permutation (Anderson et al., 2008). To investigate the spatio-temporal effects (i.e. sites and period) a 2-factor design was used with fixed factors location (loc) and period. Depending on the data, the period used was month (mo) or season (se). As the design was unbalanced at the lowest level (i.e. unequal numbers of replicate samples within each factor level of the design), it was decided to use Type I sums of squares in the analyses (Anderson et al., 2008). The lack of balance means that the various interactions and main effects cannot be estimated independently, and thus the outcome will depend on the order in which the factors are entered in the model (Anderson et al., 2008). For this study, the order used is location - month. An Euclidian distance similarity matrix was used (Clarke et al., 2006). In case of significant factor effects, pair-wise tests were performed to investigate which groups within a factor were significantly different. In case of significant interactions, pair-wise tests within the interaction were performed. Homogeneity of dispersions was tested with PERMDISP, using distances between centroids. Data were square root transformed if dispersion effect was significant. If PERMDISP was significant, even after transformation, results were interpreted with care.

To investigate the feeding strategy of pouting and to compare dietary compositions among sites, non-parametric multivariate techniques were used. All multivariate analyses were performed on prey biomass (ash-free dry weights). Prior to analysis, fourth root transformations were done to weigh the contributions of common and rare dietary categories in the similarity coefficient (Dempster et al., 2011). The similarity matrix was constructed using the Bray-Curtis index of similarity. Non-metric multidimensional scaling (MDS) was used as ordination method. The analysis of

Table 3

Age-length-key for pouting (for both sexes). Data are based on Merayo and Villegas (1994) and expressed as total length (cm). Values refer to length at the end of the year. Regression from standard length (SL) to total length (TL) is based on Hamerlynck and Hostens (1993); TL $=2.35+1.102 \mathrm{SL}$

\begin{tabular}{lll}
\hline & Male & Female \\
\hline 0 year & 20.7 & 21.4 \\
1 year & 27.5 & 26.8 \\
2 year & 31.5 & 33.1 \\
3 year & 35.6 & 38.2 \\
\hline
\end{tabular}

similarity (ANOSIM) was performed to investigate differences among sampling locations, while similarities within groups and dissimilarities between groups were calculated using similarity percentages (SIMPER).

The non-parametric Mann-Whitney $U$ test was used to compare stomach content fullness between locations. This statistical analysis was performed in R 2.15.1 software (www.r-project. org).

Multivariate analyses and PERMANOVA were performed in the Plymouth routines in multivariate ecological research (PRIMER) package, version 6.1.11 with PERMANOVA add-on software (Anderson et al., 2008; Clarke and Gorley, 2006). A significance level of $p<0.05$ was used in all tests. Results are expressed as mean \pm standard deviation (SD)

\section{Results}

\subsection{Community structure: length and age distribution}

Over the four years' sampling period, 549 and 40 Atlantic cod were caught at the WARs and Goote Bank respectively (Table 4). Lengths were ranging from 19.8 to $61.6 \mathrm{~cm}$ and weights from 70 to $2320 \mathrm{~g}$ at the WARS, while at the Goote Bank lengths were ranging from 20.7 to $40.6 \mathrm{~cm}$ and weights from 90 to $650 \mathrm{~g}$. For pouting, 824 and 96 specimens were caught respectively with lengths ranging from 12.5 to $38.5 \mathrm{~cm}$ and weights from 35 to $620 \mathrm{~g}$ at the WARs. Length ranged from 13 to $22.4 \mathrm{~cm}$ and weights from 30 to $150 \mathrm{~g}$ at the Goote Bank.

The length-frequency distribution at the WARs clearly revealed that the I-group of Atlantic cod was present year round (Fig. 2). Some II-group individuals were present as well, although in much lower numbers and mainly during the first half of the year. Thereafter, they were only sporadically encountered. At the Goote Bank only few Atlantic cod were caught and their distribution was scattered over the year. Most of them belonged to the I-group. As only few fish were caught, clear length distributions could not be obtained.

In the BPNS, 215 Atlantic cod ranging from 10 up to $93 \mathrm{~cm}$ were caught in this period (Table 4). I-group cod dominated the catches in spring, but the II- and III-groups were represented as well. Some older specimens were observed, although in very low numbers. In autumn, the 0-group dominated the catches.

In the ICES fishing area IVc, Atlantic cod up to 5 years old were observed. Age group I, II and III dominated the catches. In autumn, the 0 -group was observed as well. In this area 4384 specimens were caught and length ranged from 15 up to $98 \mathrm{~cm}$ (Table 4).

For pouting, both the 0 - and I-group were observed at the WARs (Fig. 2). The first sightings of the 0-group were in August/ September. The I-group was present year round, though was only well represented from May until October. At the Goote Bank pouting was mainly observed from September until December and only the 0 -group was encountered.

Table 4

Overview of the number of specimens available in the dataset per region for each quarter (all age groups). Q1 = Jan-Mar, Q2 = Apr-Jun, Q3 = Jul-Sep, Q4 = Oct-Dec. *Data collected in Sep and Oct.

\begin{tabular}{|c|c|c|c|c|c|c|c|c|}
\hline & \multicolumn{4}{|c|}{ Pouting } & \multicolumn{4}{|c|}{ Atlantic cod } \\
\hline & WAR & $\begin{array}{l}\text { Sandy } \\
\text { area }\end{array}$ & BPNS & IVc & WAR & $\begin{array}{l}\text { Sandy } \\
\text { area }\end{array}$ & BPNS & IVc \\
\hline Q1 & 55 & 6 & 30 & - & 38 & 16 & 104 & 418 \\
\hline Q2 & 164 & 0 & - & - & 225 & 18 & - & 1406 \\
\hline Q3 & 238 & 19 & - & - & 188 & 6 & - & 409 \\
\hline Q4 & 367 & 71 & $478^{*}$ & - & 98 & 3 & $111^{*}$ & 2151 \\
\hline Total & 824 & 96 & 508 & - & 549 & 43 & 215 & 4384 \\
\hline
\end{tabular}




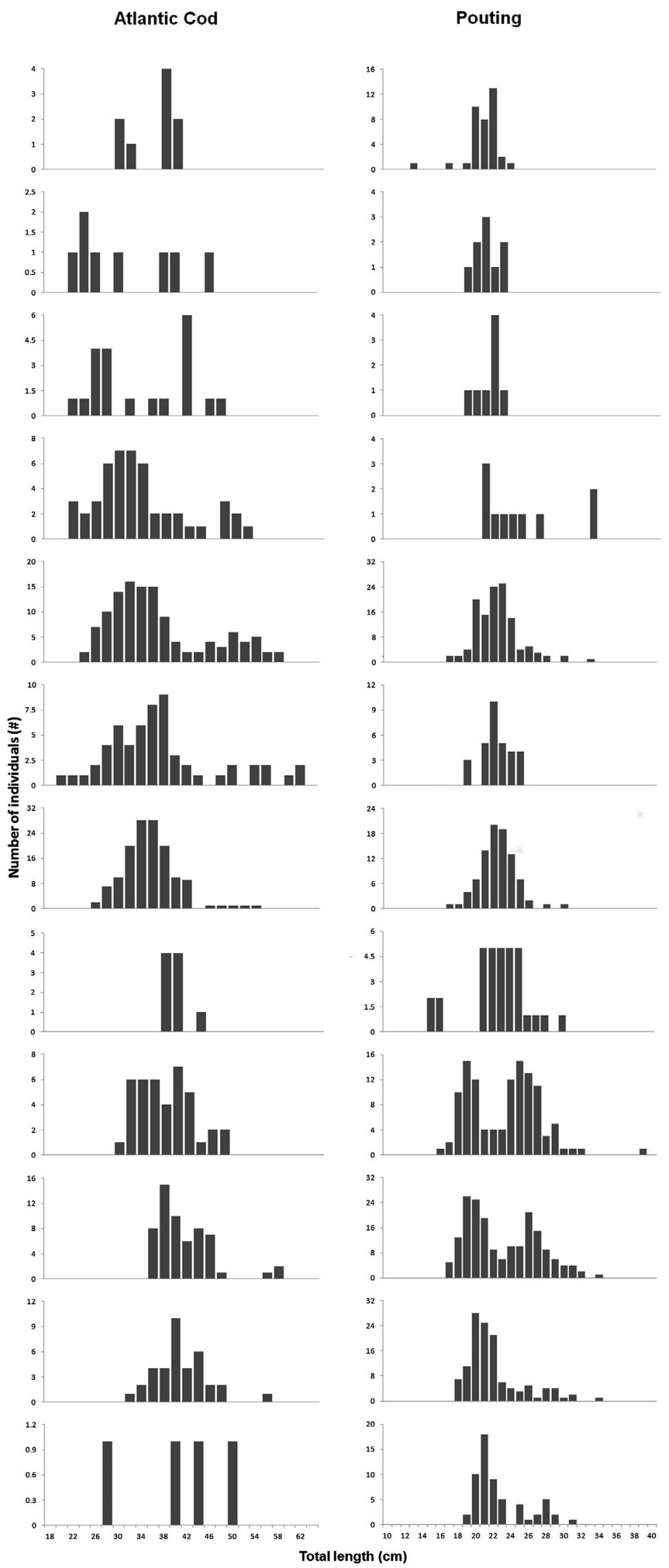

Fig. 2. Length-frequency distribution of Atlantic cod and pouting at the WARs. Values are expressed as total length $(\mathrm{cm})$. Mind the differences in scale. 
In the BPNS, 508 pouting specimens were caught, ranging from 6 to $23 \mathrm{~cm}$. The individuals caught in autumn all belonged to the $0-$ group, while in spring only the I-group was encountered. No information was available for the ICES IVc region.

\subsection{Size comparison}

Our data did not allow to compose growth curves. Only one age group was well represented and not enough data points were available from each sampling. As a result no good fit was obtained in the growth models. However, the length-frequency distributions showed some trends in growth at the WARs. For Atlantic cod, growth was observed throughout the year and was somewhat faster during winter months (Fig. 2).

For pouting on the contrary, almost no growth was observed during the winter months. From May onwards, average length increased slightly per month. For both the 0 -group and I-group an increase in average length was observed over time.

For Atlantic cod, no comparison in length between the WARs and the Goote Bank could be made due to the low catches at the sandy area (i.e. local comparison). However, a comparison was made between the WARs and the soft substrate sediments of the BPNS for the I-group. There were 89 and 111 individuals caught at the BPNS and the WARs respectively. At the sand, 45 cod were caught in spring and 44 in autumn. At the WARs, this was 16 and 95 respectively. The Atlantic cod at the sandy substrates $(24.9 \pm 3.3 \mathrm{~cm}$ in spring and $38.2 \pm 5.5 \mathrm{~cm}$ in autumn) had a comparable size to the ones at the WARs $(25.1 \pm 2.8 \mathrm{~cm}$ and $38.5 \pm 4.1)$ (Fig. 3). However, both between sites $(p=0.0001)$ and between seasons $(p=0.0001)$ length was significantly different. No interaction effect was observed ( $p=0.9$ ). Permdisp was significant for location (Table 5), which may explain the significant differences in length, notwithstanding the comparable sizes.

Likewise, length comparison was done between the WARs and the ICES area IVc (seasonally) for the I-group (Fig. 3). From these sites, 473 and 1054 individuals were analysed respectively. Significant loc $\times$ se $(p=0.0001)$ interactions in the model demonstrated that differences in length between habitats was influenced by season. Pair-wise comparisons revealed that only in quarter $2(p=0.0002)$ and $4(p=0.0001)$ significant differences in length were observed between the sites. However, it should be noted that PERMDISP was significant as well (Table 5). In quarter 2 average length was higher at the WARs, while in quarter 4 it was highest in area IVc.

A comparison in length of pouting was made between the WARs and the Goote Bank. Only the 0-group during SeptemberNovember was analysed in order to have sufficient data in both sites. Significant differences in length were revealed, both between sites $(p=0.0001)$ and between months $(p=0.0001)$. No interaction effect was observed (Table 5). At the WARs fish were bigger compared to the Goote Bank in all months (Fig. 3). For both sites length increased over months. For the I-group, no comparison was possible as this age group was not encountered at the sandy area.

A comparison in length of pouting was made between the WARs and the soft substrate sediments of the BPNS (Fig. 3). In total 508 pouting were caught in the BPNS. Only 30 individuals were caught in spring, while 478 were caught in autumn. For the WARs 158 individuals could be used for comparison; 8 and 150 individuals for spring and autumn respectively. For the comparison in autumn fish belonged to the 0-group, while in spring they already belonged to the I-group. Significant differences in length were revealed, both between sites $(p=0.0001)$ and between seasons $(p=0.0001)$. No interaction effect was observed ( $p=0.24$ ). PERMDISP was significant for location (Table 5). At the WARs pouting were bigger $(18.8 \pm 1.5$ and $20.5 \pm 1.4 \mathrm{~cm})$ compared to the BPNS $(15.6 \pm 2.3$ and $17.6 \pm 2.4 \mathrm{~cm})$ in autumn and spring respectively.

No comparison could be made for ICES area IVc.

\subsection{Condition and diet analysis - pouting}

For pouting, the condition index could be compared between the WARs and the Goote Bank in late summer and autumn, but no significant differences were detected $(p=0.21)$ between the sites. However, condition differed significantly between SeptemberOctober and September-November $(p=0.06$ and $p=0.07$ respectively). In September the Fulton condition index was somewhat lower compared to the other months (Fig. 4).

Condition could not be investigated for the regional sites because no information on individual weight was available.

Stomach contents were compared between the WARs and the Goote Bank for pouting caught in October-November 2011. There were 43 and 17 stomachs analysed for the WARs and the Goote Bank respectively. One empty stomach $(2.3 \%)$ was present at the

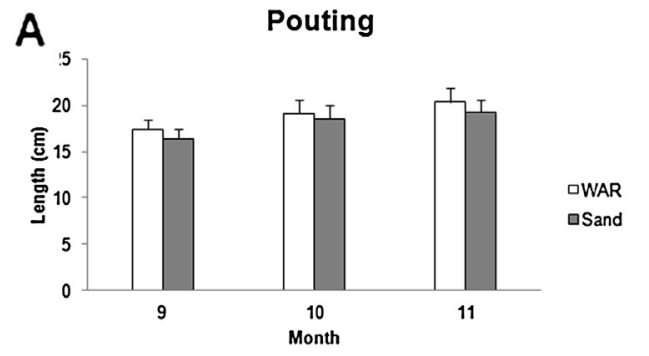

B
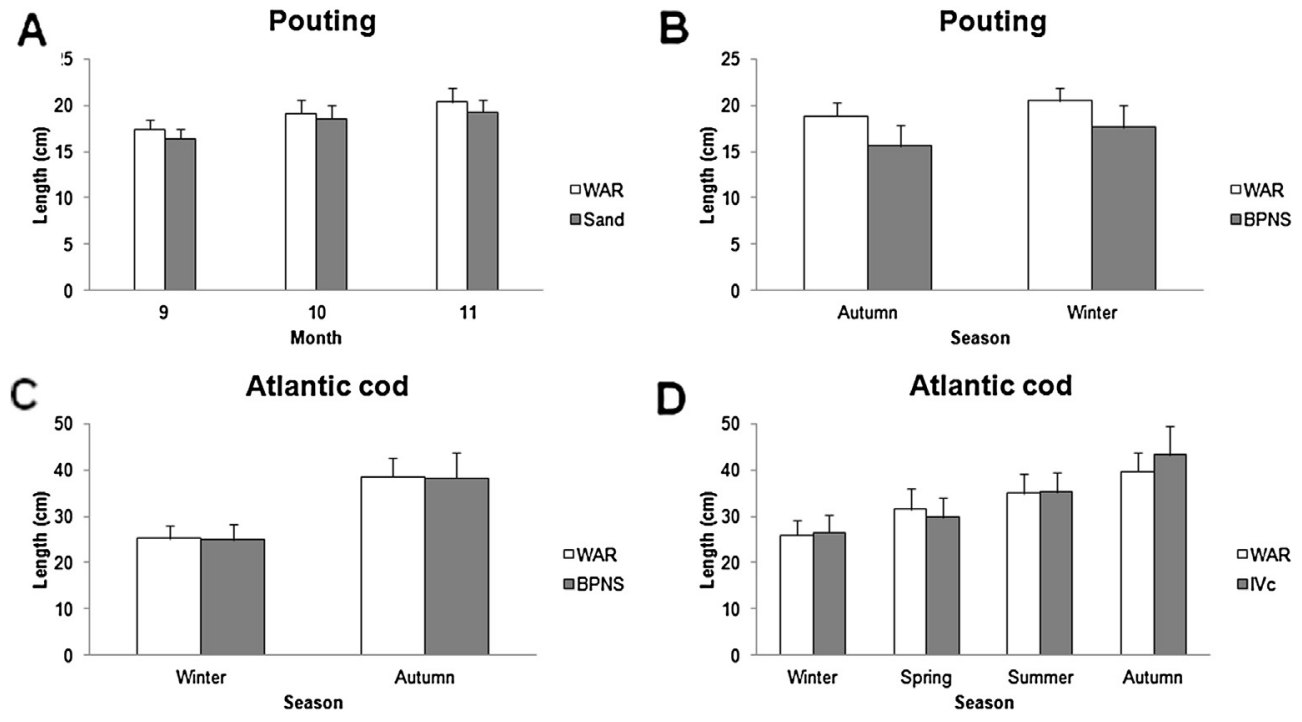

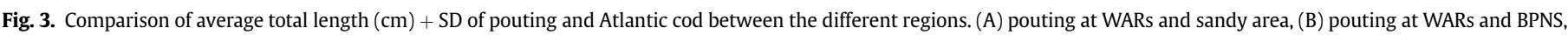
(C) Atlantic cod at WARs and BPNS, (D) Atlantic cod at WARs and ICES area IVc. 
Table 5

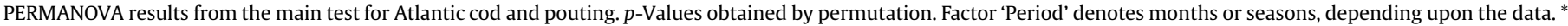
PERMDISP significant; ${ }^{* *}$ Square root transformed.

\begin{tabular}{|c|c|c|c|c|c|c|c|c|c|c|c|c|c|}
\hline & & \multicolumn{4}{|c|}{ Location } & \multicolumn{4}{|c|}{ Period } & \multicolumn{4}{|c|}{ Location $\times$ Period } \\
\hline & & df & MS & Pseudo- $F$ & $p$ & df & MS & Pseudo- $F$ & $p$ & df & MS & Pseudo- $F$ & $p$ \\
\hline \multirow[t]{3}{*}{ Pouting } & Length (local) & 1 & 88.5 & 43.7 & 0.0001 & 2 & 90.5 & 44.7 & 0.0001 & 2 & 1.1 & 0.5 & 0.6 \\
\hline & Length (BPNS)** & 1 & 18.6 & 240 & $0.0001^{*}$ & 1 & 2 & 25.7 & 0.0001 & 1 & 0.02 & 0.26 & $0.6^{*}$ \\
\hline & Fulton index** & 1 & 0.01 & 1.6 & 0.2 & 2 & 0.05 & 5.2 & 0.007 & 2 & 0.02 & 1.8 & 0.2 \\
\hline \multirow[t]{2}{*}{ Cod } & Length (BPNS)** & 1 & 1478.7 & 93.9 & $0.0001^{*}$ & 3 & 2214 & 140.6 & $0.0001^{*}$ & 3 & 20 & 1.3 & 0.3 \\
\hline & Length (ICES IVc)** & 1 & 57 & 315.2 & $0.0001^{*}$ & 3 & 93.6 & 517.5 & $0.0001^{*}$ & 3 & 2.6 & 14.4 & $0.0001^{*}$ \\
\hline
\end{tabular}

WARs, none at the sandy area. However, the average stomach fullness was significantly higher (non-parametric Mann-Whitney $U$ test, $p=0.02)$ at the WARs $(1.5 \pm 1.4)$ compared to the Goote Bank $(0.6 \pm 0.8)$. The 2 -dimensional MDS plot and Simper analysis, based on ash-free dry weights of the prey groups, revealed that the diets of fish from the WARs were more clustered and similar (average similarity 59\%), while the ones from the Goote Bank had a more diverse composition (average similarity 37\%). ANOSIM indicated that significant differences in diets were present between the two sites ( $R=0.5, p=0.0001)$. The diets of pouting at the WARs were dominated by Amphipoda, followed by Reptantia, while the fish at the Goote Bank were characterized by more diverse diets with Pisces, Reptantia, Anthozoa and Amphipoda as the most important prey groups (Table 6). A more detailed analysis of the individual prey species showed that pouting at the WARs mainly fed upon hard substrate associated prey species (i.e. Jassa herdmani, Pisidia longicornis and Liocarcinus holsatus), while at the sandy area they fed both on hard and soft substrate associated prey species (i.e. Callionymus sp., Actiniaria sp., polychaeta sp. and L. holsatus) (Table 6).

\section{Discussion}

We demonstrated that at the investigated WARs specific lengths and age groups were present in the catches of Atlantic cod and pouting. For Atlantic cod this was the I-group, while for pouting the 0 - and I-group dominated the catches. Although not represented in the samples, other age groups may be present as well at this habitat. The smallest cod observed measured $20 \mathrm{~cm}$, and nearly all pouting were larger than $15 \mathrm{~cm}$. Scuba divers performing visual surveys (Reubens et al., 2011) on the other hand, observed Atlantic cod as small as $5 \mathrm{~cm}$ and pouting of $10 \mathrm{~cm}$ at the WARs. This suggests that other age groups are present but not efficiently caught using hook and line. Line fishing is a selective fishing technique and type and size of baits, hook design, fishing strategy and fish ecology

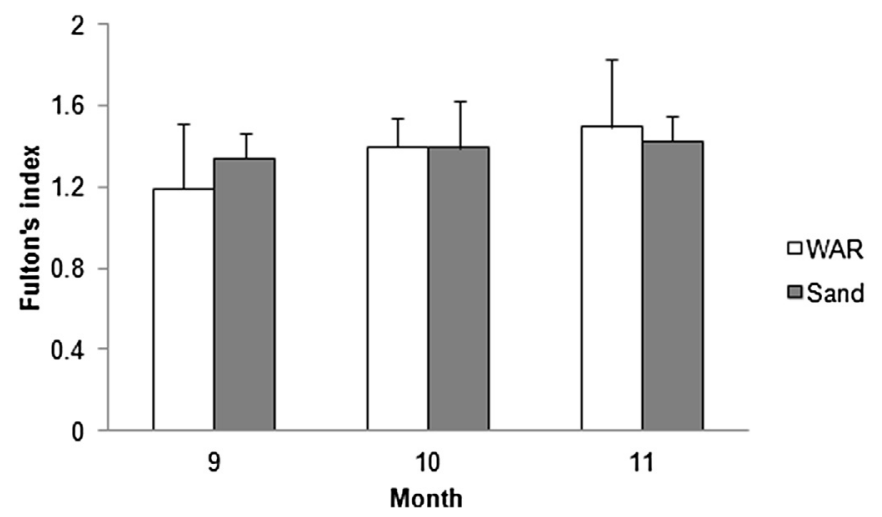

Fig. 4. Average fulton's condition index $(+S D)$ of pouting at the WARs and the sandy area. all may influence the species and size selectivity (Løkkeborg and Bjordal, 1992). Prey preferences of fish are related to prey size (Daan, 1973), thus size of bait and hooks will influence the fish size caught. In this study we used small hooks (Arca nr 4) and live bait (the lugworm A. marina). The size of the hook induces a lower and upper limit of fish sizes able to be caught. For small fish the hook may be too big, while big fish may no longer be efficiently hooked (Løkkeborg and Bjordal, 1992).

In beam trawl fishing mesh size, configuration and number of meshes in the circumference and towing speed influence fish sizes caught (Campos et al., 2003; Herrmann et al., 2007); however, it is still much less selective compared to line fishing. This may partly explain the difference in age groups present in the catches. In the trawl catches Atlantic cod from 0 to 5 years old were observed.

It is notable that at the soft substrates (both locally and nationally) only the 0-group of pouting was observed in autumn. At the WARs the I-group was present as well. This suggests that larger individuals need hard substrates as they were not encountered at the sandy areas but dominated at the WARs. Literature information (Merayo, 1996a) confirms this result.

It was shown that pouting at the WARs is somewhat larger compared to the ones at the sandy substrates, while Fulton's condition index was comparable between both habitat types. To achieve growth, the food intake should be higher than the energy required to maintain the fish metabolism. The energy required for metabolism in turn depends on a multitude of environmental factors (e.g. food availability, currents, temperature). If environmental conditions allow optimal energy gain, more energy will be available for growth. Løkkeborg and Fernö (1999) showed that, although Atlantic cod may feed throughout the $24 \mathrm{~h}$ cycle of a day, their feeding behaviour is expected to reflect a style resulting in this optimal energy gain. As environmental factors differ between habitats, the energy gain may differ per habitat. At the WARs many hiding places against currents and predators are present, reducing energetic costs of swimming. In addition, a lot of potential prey species are available in high densities (Reubens et al., 2013b). This may explain the differences in length-at-age of pouting between the WARs and the sandy bottom sediments.

For Atlantic cod, significant differences in size were revealed between the WARs and both the BPNS and ICES area IVc, despite the comparable average lengths. In the PERMANOVA model the assumption for homogeneity of dispersions was not fulfilled for loc $\times$ se; PERMDISP had a $p$-value below 0.05 . This means that a significant result is caused by a significant difference in dispersion or some combination of location and dispersion between the groups (Anderson et al., 2008). As average lengths were comparable (Fig. 3), differences were probably related to the dispersion effect.

Although only few stomachs from individuals caught at the Goote Bank were available for analysis, some interesting results were obtained concerning the diet of pouting. Average stomach fullness was much elevated at the WARs compared to the Goote Bank and diet composition differed significantly between both sites. It is striking that at the WARs all dominant prey items were 
Table 6

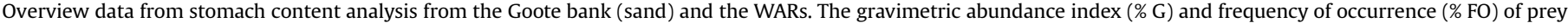
groups present in the stomachs of pouting are listed in the left column. In the right column the 5 most important prey species (in terms of weight) are listed.

\begin{tabular}{|c|c|c|c|c|c|c|c|c|}
\hline & \multicolumn{2}{|l|}{$\% \mathrm{G}$} & \multicolumn{2}{|l|}{$\% \mathrm{FO}$} & \multicolumn{4}{|l|}{$\% \mathrm{G}$} \\
\hline & Sand & WAR & Sand & WAR & & Sand & & WAR \\
\hline Amphipoda & 8.1 & 66.8 & 64.7 & 94.1 & Callionymus sp. & 43.14 & Jassa herdmani & 61.97 \\
\hline Anthozoa & 9.7 & 0.0 & 5.9 & 0.0 & Pisces spec. & 9.82 & Pisidia longicornis & 10.22 \\
\hline Detritus & 0.1 & 0.3 & 5.9 & 5.9 & Actiniaria sp. & 9.69 & Pisces sp. & 8.42 \\
\hline Echinodermata & 0.1 & 0.0 & 5.9 & 0.0 & Polychaeta sp. & 4.72 & Liocarcinus holsatus & 5.45 \\
\hline Mollusca & 0.1 & 0.0 & 17.6 & 5.9 & Liocarcinus holsatus & 4.28 & Necora puber & 3.05 \\
\hline Mysidacea & 1.4 & 0.0 & 11.8 & 5.9 & & & & \\
\hline Natantia & 4.4 & 0.3 & 29.4 & 2.9 & & & & \\
\hline Pisces & 53.0 & 8.4 & 23.5 & 5.9 & & & & \\
\hline Reptantia & 15.8 & 22.9 & 76.5 & 79.4 & & & & \\
\hline Rest & 7.4 & 1.2 & 76.5 & 55.9 & & & & \\
\hline
\end{tabular}

associated with the hard substrates. These prey species occur in very high densities (up to 20,000; and $4000 \mathrm{ind} / \mathrm{m}^{2}$ for J. herdmani and $P$. longicornis respectively) here (Kerckhof et al., 2010). Pouting from the Goote Bank on the other hand had a more diverse diet and similarity in dietary items was much lower within this habitat compared to the WARs. They both fed on hard and soft substrate associated prey, which may be an indication that these specimens have to spend more energy for sufficient food intake as they move forth and back between hard and soft substrates. The lower fullness index signifies the lower food availability in this habitat. A recent study (Reubens et al., 2011) on the stomach content analysis of pouting caught near the wind farms in the BPNS revealed that the tube building amphipod J. herdmani and the long-clawed porcelain crab $P$. longicornis are the most important prey species, which is confirmed in this study. Though they are dominant in the diet, they are not necessarily a profitable energy source. Therefore, De Troch et al. (2013) have calculated the proximate composition (i.e. quantifying the levels of carbohydrates, lipids and proteins in the tissue in order to determine the total available energy) for both prey species. Especially J. herdmani had a high proximate composition and thus energy available. It is a lipid-rich food source. Other than energy requirements, fish also have fatty acid requirements. Mainly essential fatty acids are important, as higher organisms cannot synthesize these themselves but should gain them from their food sources (Dalsgaard et al., 2003). Both in J. herdmani and in $P$. longicornis a considerable amount of essential fatty acids (i.e. EPA and DHA) were found (De Troch et al., 2013) rendering them potentially important prey types.

Based on the information of the current study no evidence was obtained to assume that the WARs act as an ecological trap for Atlantic cod and pouting (related to habitat quality). For Atlantic cod length was comparable to the length of individuals at the local and regional reference sites. As a result, it may be concluded that the fitness of Atlantic cod at the WARs was similar to the one at the sandy reference areas. Length of pouting at the WARs was slightly larger compared to individuals at the sandy areas, while no significant differences in condition were observed between sites. In addition, food was plentiful at the WARs and no restrictions related to sufficient food intake were encountered. Based on the measured proxies, fitness of pouting was even slightly better compared to the sandy areas (increased length and enhanced fullness index). This might be a first indication towards production (i.e. increased biomass) of pouting at the WARs.

It should be annotated that the current results do not exclude the WARs to act as an ecological trap via increased fishing mortality. Fish aggregations are particularly vulnerable to fishing pressure (Rose and Kulka, 1999). Concentration of both fish and fisheries activities can lead to local overfishing. If uncontrolled fisheries would be allowed at the WARs, fish aggregating in this habitat would experience enhanced mortalities (i.e. fishing mortality), and they would thus be caught in an ecological trap. However, so far the wind farm concession areas in the BPNS exclude all fisheries activities. As a consequence, fish aggregating in this habitat are released from exploitation pressure; resulting in higher survival chances (i.e. less fishing mortality). This might lead to an increasing production of the population, aside from fitness issues. From a management perspective, it is therefore essential to keep OWF closed to fisheries. Only by doing so, the beneficial effects of wind farms on fish can be transferred to the entire ecosystem. More research is demanded to assess the effect of fisheries closure on the fish population levels.

In this study, only one wind farm was sampled. In ideal conditions replicates should be taken to investigate life history traits of Atlantic cod and pouting, but sampling multiple wind farms is logistically challenging. However, the selected sandy reference sites are unlikely to vary considerably in environmental factors (i.e. temperature, salinity, current conditions, sediment characteristics) from the wind farm.

The integration of data from local, national (BPNS) and regional (ICES area IVc) levels allowed for appropriate data interpretation on a broader scale, increasing the relevance of the study. However, more information on condition and diet composition (mainly for Atlantic cod) are highly recommended.

\section{Acknowledgement}

The first author acknowledges a doctoral grant from the Fund for Scientific Research - Flanders (FWO 1.1.075.10.N.00). Further support for the work was provided by the Flemish Government and the European Commission (through the Data Collection Framework). This research was facilitated by the Flanders Marine Institute (VLIZ) and the Management Unit of the North Sea Mathematical Models (MUMM). We thank the ship owners, crew and on-board observers for their assistance in the discard sampling programme. We thank the crew of the RV Simon Stevin and RV Belgica, the numerous colleagues and students for their assistance in the field. This paper contributes to the Belgian wind farm monitoring programme, with the financial support of C-Power nv, Belwind nv and Northwind nv.

\section{References}

Amundsen, P.A., Gabler, H.M., Staldvik, F.J., 1996. A new approach to graphical analysis of feeding strategy from stomach contents data-modification of the Costello method. Journal of Fish Biology 48, 607-614.

Anderson, M.J., Gorley, R.N., Clarke, K.R., 2008. PERMANOVA+ for PRIMER: Guide to Software and Statistical Methods. Primer-e, Plymouth, UK. 
Andersson, M.H., Berggren, M., Wilhelmsson, D., Öhman, M.C., 2009. Epibenthic colonization of concrete and steel pilings in a cold-temperate embayment: a field experiment. Helgoland Marine Research 63, 249-260.

Arapogianni, A., Moccia, J., Wilkes, J., 2013. The European Offshore Wind Industry Key Trends and Statistics 2012. European Wind Energy Association, Brussels, p. 31

Brabant, R., Degraer, S., Rumes, B., 2012. Offshore wind energy development in the Belgian part of the North Sea \& anticipated impacts: an update. In: Degraer, S., Brabant, R., Rumes, B. (Eds.), Offshore Wind Farms in the Belgian Part of the North Sea: Selected Findings from the Baseline and Targeted Monitoring. Royal Belgian Institute of Natural Sciences, Management Unit of the North Sea Mathematical Models. Marine Ecosystem Management Unit, Brussels, pp. 9-16.

Brickhill, M.J., Lee, S.Y., Connolly, R.M., 2005. Fishes associated with artificial reefs: attributing changes to attraction or production using novel approaches. Journal of Fish Biology 67, 53-71.

Campos, A., Fonseca, P., Henriques, V., 2003. Size selectivity for four fish species of the deep groundfish assemblage off the Portuguese southwest coast: evidence of mesh size, mesh configuration and cod end catch effects. Fisheries Research $63,213-233$.

Clarke, K.R., Gorley, R.N., 2006. PRIMER V6: User Manual/Tutorial. PRIMER-E, Plymouth, UK.

Clarke, K.R., Somerfield, P.J., Chapman, M.G., 2006. On resemblance measures for ecological studies, including taxonomic dissimilarities and a zero-adjusted Bray-Curtis coefficient for denuded assemblages. Journal of Experimental Marine Biology and Ecology 330, 55-80.

Daan, N., 1973. A quantitative analysis of the food intake of North Sea cod, Gadus morhua. Netherlands Journal of Sea Research 6, 479-517.

Daan, N., 1974. Growth of North Sea cod, Gadus morhua. Netherlands Journal of Sea Research 8, 27-48.

Dalsgaard, J., St John, M., Kattner, G., Müller-Navarra, D., Hagen, W., 2003. Fatty acid trophic markers in the pelagic marine environment. Advances in Marine Biology 46, 225-340.

De Troch, M., Reubens, J., Heirman, E., Degraer, S., Vincx, M., 2013. Energy Profiling of Demersal Fish: a Case-study in Wind Farm Artificial Reefs (submitted for publication).

Degraer, S., Wittoeck, J., Appeltans, W., Cooreman, K., Deprez, T., Hillewaert, H., Hostens, K., Mees, J., Vanden Berghe, E., Vincx, M., 2006. The Macrobenthos Atlas of the Belgian Part of the North Sea. Belgian Science Policy. D/2005/1191/6.

Dempster, T., Sanchez-Jerez, P., Fernandez-Jover, D., Bayle-Sempere, J., Nilsen, R., Bjørn, P.A., Uglem, I., 2011. Proxy measures of fitness suggest coastal fish farms can act as population sources and not ecological traps for Wild gadoid fish. PloS One 6.

Hallier, J.P., Gaertner, D., 2008. Drifting fish aggregation devices could act as an ecological trap for tropical tuna species. Marine Ecology Progress Series 353, 255-264.

Hamerlynck, O., Hostens, K., 1993. Growth, feeding, production and consumption in 0-group bib (Trisopterus luscus $\mathrm{L}$ ) and whithing (Merlangius merlangus L) in a shallow coastal area of the South-West Netherlands. Ices Journal of Marine Science 50, 81-91.

Herrmann, B., Priour, D., Krag, L.A., 2007. Simulation-based study of the combined effect on cod-end size selection of turning meshes by 90 and reducing the number of meshes in the circumference for round fish. Fisheries Research 84, $222-232$.

ICES, 2012. Report of the Working Group on the Assessment of Demersal Stocks in the North Sea and Skaggerrak (WGNSSK), 4-10 May 2011. ICES Headquarters, Copenhagen, p. 1197. ICES CM 2011/ACOM:13.

Jones, L.A., Coyle, M.D., Evans, D.A., Gilliland, P.M., Murray, A.R., 2004. Southern North Sea Marine Natural Area Profile: A Contribution to Regional Planning and Management of the Seas Around England. English Nature, Petersborough, UK, p. 102.

Kerckhof, F., Houziaux, J.S., 2003. Biodiversity of the Belgian marine areas. In: Peeters, M., Franklin, A., Van Goethem, J. (Eds.), Biodiversity in Belgium. Royal Belgian Institute of Natural Sciences, Brussel, pp. 350-385.

Kerckhof, F., Rumes, B., Norro, A., Jacques, T.G., Degraer, S., 2010. Seasonal variation and vertical zonation of the marine biofouling on a concrete offshore windmill foundation on the Thornton Bank (southern North Sea). In: Degraer, S., Brabant, R., Rumes, B. (Eds.), Offshore Wind Farms in the Belgian Part of the
North Sea: Early Environmental Impact Assessment and Spatio-Tempora Variability. Royal Belgian Institute of Natural Sciences. Management Unit of the North Sea Mathematical Models. Marine Ecosystem Management Unit Brussels, pp. 53-68.

Lambert, Y., Dutil, J.D., 1997. Condition and energy reserves of Atlantic cod (Gadus morhua) during the collapse of the northern Gulf of St. Lawrence stock. Canadian Journal of Fisheries and Aquatic Sciences 54, 2388-2400.

Leonhard, S.B., Stenberg, C., Støttrup, J., 2011. Effect of the Horns Rev 1 Offshore Wind Farm on Fish Communities Follow-up Seven Years after Construction, Molecular Ecology. DTU Aqua, Orbicon, DHI, NaturFocus. Report commissioned by The Environmental Group through contract with Vattenfall Vindkraft A/S DTU Aqua Report NO 246-2011. National Institute of Aquatic Resources, Technical University of Denmark, p. 66 + Appendices.

Lindberg, W.J., 1997. Can science resolve the attraction-production issue? Fisheries $22,10-13$.

Løkkeborg, S., Bjordal, A., 1992. Species and size selectivity in longline fishing: a review. Fisheries Research 13, 311-322.

Løkkeborg, S., Fernö, A., 1999. Diel activity pattern and food search behaviour in cod Gadus morhua. Environmental Biology of Fishes 54, 345-353.

Mallefet, J., Zintzen, V., Massin, C., Norro, A., vincx, M., De Maersschalck, V., Steyaert, M., Degraer, S., Cattrijsse, A., 2008. Belgian Shipwreck: Hotspots for Marine Biodiversity (BEWREMABI). Belgian Science Policy Office, Brussels, p. 155.

Merayo, C.R., 1996a. Reproduction and fecundity of the bib Trisopterus luscus (Linnaeus, 1758) (Pisces, Gadidae) in the central region of the Cantabrian Sea (northern Spain). Boletín del Instituto Español de Oceanografía 12, 17-29.

Merayo, C.R., 1996b. Seasonal changes in the biochemical composition of the muscle and liver of bib (Trisopterus luscus L.) (Pisces, Gadidae) from the Cantabrian Sea (N Spain). Scientia Marina 60, 489-495.

Merayo, C.R., Villegas, M.L., 1994. Age and growth of Trisopterus luscus (Linnaeus, 1758) (Pisces, Gadidae) off the coast of Asturias. Hydrobiologia 281, 115-122.

Merckx, B., 2011. Habitat Suitability and Community Modelling of Marine Benthos. Biology Department. Ghent University, Ghent, p. 309.

Pickering, H., Whitmarsh, D., 1997. Artificial reefs and fisheries exploitation: a re view of the 'attraction versus production' debate, the influence of design and its significance for policy. Fisheries Research 31, 39-59.

Reubens, J., Braeckman, U., Vanaverbeke, J., Van Colen, C., Degraer, S., Vincx, M. 2013a. Aggregation at windmill artificial reefs: CPUE of Atlantic cod (Gadus morhua) and pouting (Trisopterus luscus) at different habitats in the Belgian part of the North Sea. Fisheries Research 139, 28-34.

Reubens, J., De Rijcke, M., Degraer, S., Vincx, M., 2013b. Diel variation in feeding and activity patterns of juvenile Atlantic cod at offshore wind farms. Journal of Sea Research (in press).

Reubens J., Pasotti F., Degraer S., Vincx M., Residency, site fidelity and habitat use of Atlantic cod (Gadus morhua) at an offshore wind farm using acoustic telemetry, Marine Environmental Research (submitted for publication)

Reubens, J., Degraer, S., Vincx, M., 2011. Aggregation and feeding behaviour of pouting (Trisopterus luscus) at wind turbines in the Belgian part of the North Sea. Fisheries Research 108, 223-227.

Reubens, J., Eede, V., Vincx, M., 2009. Monitoring of the effects of offshore wind farms on the endobenthos of soft substrates: year-0 Bligh bank and year-1 Thorntonbank. In: Degraer, S., Brabant, R. (Eds.), Offshore Wind Farms in the Belgian Part of the North Sea: State of the Art after Two Years of Environmental Monitoring. Royal Belgian Institute of Natural Sciences. Management Unit of the North Sea Mathematical Models. Marine Ecosystem Management Unit, Brussels, pp. 59-91.

Robertson, B.A., Hutto, R.L., 2006. A framework for understanding ecological traps and an evaluation of existing evidence. Ecology 87, 1075-1085.

Rose, G.A., Kulka, D.W., 1999. Hyperaggregation of fish and fisheries: how catch-perunit-effort increased as the northern cod (Gadus morhua) declined. Canadian Journal of Fisheries and Aquatic Sciences 56, 118-127.

Schlaepfer, M.A., Runge, M.C., Sherman, P.W., 2002. Ecological and evolutionary traps. Trends in Ecology \& Evolution 17, 474-480.

Winter, H.V., Aarts, G., van Keeken, O.A., 2010. Residence Time and Behaviour of Sole and Cod in the Offshore Wind Farm Egmond Aan Zee (OWEZ). IMARES, Wageningen YR. Report number: C038/10, p. 50. 